\title{
KOMBINASI PULSED SHORTWAVE THERAPY DAN NEURODYNAMIC MOBILIZATION LEBIH EFEKTIF MENURUNKAN DISABILITAS PUNGGUNG DIBANDINGKAN KOMBINASI PULSED SHORTWAVE THERAPY DAN LUMBAR SPINE STABILIZATION EXERCISE PADA PASIEN HERNIA NUKLEUS PULPOSUS LUMBOSAKRAL
}

\author{
Made Hendra Satria Nugraha ${ }^{1}$, Susy Purnawati ${ }^{2}$, Muh. Irfan ${ }^{3}$, Luh Made Indah Sri Handari \\ Adiputra $^{4}$, I Made Muliarta ${ }^{5}$, Wahyuddin 6 \\ ${ }^{1}$ Program Studi Magister Fisiologi Olahraga Universitas Udayana Bali \\ ${ }^{2,4,5}$ Fakultas Kedokteran Universitas Udayana Bali \\ ${ }^{3}$ Program Studi Sarjana \& Profesi Fisioterapi, Fakultas Ilmu Kesehatan, \\ Universitas Aisyiyah Yogyakarta \\ ${ }^{6}$ Fakultas Fisioterapi Universitas Esa Unggul Jakarta
}

\begin{abstract}
ABSTRAK
Pendahuluan: Hernia nukleus pulposus adalah suatu kondisi kerusakan dimana terjadi protrusi dari anulus fibrosus beserta nukleus pulposus ke lumen kanalis vertebralis. Tujuan: Untuk mengetahui perbedaan efektivitas kombinasi pulsed shortwave therapy dan lumbar spine stabilization exercise dengan kombinasi pulsed shortwave therapy dan neurodynamic mobilization dalam menurunkan disabilitas punggung pada pasien hernia nukleus pulposus lumbosakral di klinik Fisioterapi Badung dan Denpasar. Metode: Penelitian ini merupakan penelitian eksperimental. Pre dan post test control group design merupakan rancangan penelitian ini. Penelitian ini menggunakan 28 subjek, terbagi dalam 2 kelompok, dimana kelompok kontrol $(\mathrm{n}=14)$ mendapatkan intervensi kombinasi pulsed shortwave therapy dan lumbar spine stabilization exercise sedangkan kelompok perlakuan $(\mathrm{n}=14)$ mendapatkan intervensi kombinasi pulsed shortwave therapy dan neurodynamic mobilization. Intervensi diberikan $2 \mathrm{x}$ seminggu selama 4 minggu. Tehnik pengambilan sampel dengan random sampling. Disabilitas punggung diukur dengan modified oswestry disability index. Hasil: Uji normalitas data menggunakan Saphiro-Wilk test sedangkan uji homogenitas menggunakan Levene's test. Terdapat hasil uji yang signifikan pada kelompok kontrol dengan nilai $\mathrm{p}=0,001$. Pada kelompok perlakuan didapatkan pula perbedaan yang signifikan dengan nilai $\mathrm{p}=0,001$. Uji post-test antar kelompok dengan mann-whitney u-test menunjukkan adanya perbedaan yang bermakna antara kelompok kontrol dan kelompok perlakuan dengan nilai $\mathrm{p}=0,044$. Persentase penurunan disabilitas pada kelompok kontrol sebesar 48,53\% dan pada kelompok perlakuan sebesar 54,88\%. Simpulan: Kombinasi pulsed shortwave therapy dan neurodynamic mobilization lebih efektif daripada kombinasi pulsed shortwave therapy dan lumbar spine stabilization exercise dalam menurunkan disabilitas punggung pada pasien hernia nukleus pulposus lumbosakral di klinik Fisioterapi Badung dan Denpasar.
\end{abstract}

Kata kunci: hernia nukleus pulposus lumbosakral, disabilitas punggung, pulsed shortwave therapy, neurodynamic mobilization, lumbar spine stabilization exercise 


\title{
THE COMBINATION OF PULSED SHORTWAVE THERAPY AND NEURODYNAMIC MOBILIZATION IS MORE DECREASING LOW BACK DISABILITY RATHER THAN THE COMBINATION OF PULSED SHORTWAVE THERAPY AND LUMBAR SPINE STABILIZATION EXERCISE ON LUMBOSACRAL HERNIATED NUCLEUS PULPOSUS PATIENTS
}

\begin{abstract}
ABTSRACT
Introduction: Herniated Nucleus Pulposus (HNP) is a pathological condition in which there is protrusion of the annulus fibrosus and nucleus pulposus into the lumen of the vertebral canal. Objective: The goal of this study is to determine the effectiveness of combination of pulsed shortwave therapy and lumbar spine stabilization exercise with combination of pulsed shortwave therapy and neurodynamic mobilization in decreasing low back disability in lumbosacral herniated nucleus pulposus patients at Denpasar and Badung Physiotherapy Clinic. Methods: The study used was an experimental method. Pre-test and post-test control group design is the design of this study. This study used 28 subjects were divided into two groups. The control group consist of 14 subjects received a combination of pulsed shortwave therapy and lumbar spine stabilization exercise while the treatment group consist of 14 subjects received a combination of pulsed shortwave therapy and neurodynamic mobilization. Intervention is given 2 times a week for 4 weeks. Sampling methods used in this study was simple random sampling. The low back disability is measured by a modified oswestry disability index. Result: The normality test of the data was tested using Saphiro-Wilk Test and homogeneity test of the data was tested with Levene's Test. Wilcoxon sign rank test results obtained significant differences in the control group with the value of $p=0.001$, as well as in the treatment group found a significant difference with the value of $p=0.001$. Post-test results with mann-whitney u-test showed a significant difference between the control group and the treatment group where $p=0.044$ with the percentage of $48.53 \%$ in the control group and $54.88 \%$ in the treatment group. Conclusion: Based on the results of this study it can be concluded that the combination of pulsed shortwave therapy and neurodynamic mobilization is more effective than the combination of pulsed shortwave therapy and lumbar spine stabilization exercise in reducing low back disability in patients with lumbosacral herniated nucleus pulposus at the Denpasar and Badung Physiotherapy Clinic.
\end{abstract}

Keywords: lumbosacral herniated nucleus pulposus, low back disability, pulsed shortwave therapy, neurodynamic mobilization, lumbar spine stabilization exercise

\section{PENDAHULUAN}

Hernia Nukleus Pulposus adalah salah satu penyebab nyeri punggung bawah. Insiden HNP di Amerika Serikat adalah sekitar 5\% dari populasi orang dewasa. Kejadian HNP yang paling sering yaitu lesi pada diskus intervertebralis L4-L5 dan L5-S1. Sedangkan pada regio servikal yaitu pada C5-C6 dan C6C7. Regio torakalis merupakan daerah yang paling jarang terkena. ${ }^{1}$

HNP lumbosakral merupakan suatu sindrom yang terdiri atas beberapa gejala, seperti: kekakuan yang dikarenakan refleks spasme dari otot-otot paravertebral, nyeri punggung bawah yang meluas ke paha bagian posterior, gluteal, cruris hingga ke pedis, kelemahan pada otot-otot sekitar punggung dan kaki, atau kelemahan refleks tendon patella dan achilles yang mengarah kepada suatu disabilitas punggung. ${ }^{2}$

Pendekatan terapi konservatif yang dapat diberikan pada pasien HNP lumbosakral, meliputi pengaplikasian modalitas dan terapi oleh fisioterapi, yaitu melalui pemberian modalitas electrophysical agents, exercise therapy/terapi latihan, serta intervensi manual therapy. Jika pendekatan penanganan HNP hanya terbatas pada aplikasi berupa terapi latihan ataupun manual terapi maka penanganan yang diberikan menjadi 
kurang efektif. Terlebih lagi, penanganan di klinik fisioterapi masih menggunakan superficial heating seperti infrared sebagai modalitas elektroterapi. Oleh karena itu, dibutuhkan modalitas elektroterapi yang mampu menghasilkan efek non-thermal dengan penetrasi yang cukup dalam seperti aplikasi Pulsed Shortwave Therapy (PSWT). Aplikasi PSWT ini dapat digunakan sebagai terapi standar dalam penanganan HNP lumbosakral.

Penelitian (Ye, et.al., 2015) membuktikan terdapat peningkatan signifikan terhadap penurunan skor disabilitas punggung pada penderita HNP setelah diberikan lumbar spine stabilization exercise (LSSE). Adapun proses pelatihannya terdiri atas: kontraksi isometric lumbar multifidus dan transversus abdominis, curl-up, pelvic bridge, side bridge, quadruped position with alternate arm/leg raises, prone plank, serta ditingkatkan progressnya dengan melakukan dynamic movement menggunakan ball/foam roll. ${ }^{3}$

Intervensi lain yang dapat diberikan pada penderita HNP lumbosakral yaitu: pendekatan manual terapi dengan intervensi neural/neurodynamic mobilization. Neurodynamic mobilization adalah pendekatan manial terapi yang berfokus kepada konsep fisiologis dan mekanik dari sistem saraf yang berintegrasi dengan sistem muskuloskeletal. Teknik ini bertujuan untuk meningkatkan mobilitas sistem saraf pada mechanical interface-nya. ${ }^{4}$

Penanganan yang hanya berfokus kepada pemberian modalitas elektroterapi saja atau dalam hal ini PSWT membuat efek terapi menjadi kurang efektif. Oleh karena itu dibutuhkan suatu kombinasi dalam pemberian intervensi. Pada penelitian ini, kombinasi yang diberikan yaitu aplikasi PSWT dengan lumbar spine stabilization exercise (LSSE) dan aplikasi PSWT dengan neurodynamic mobilization (NM). Sehingga diharapkan penurunan skor disabilitas punggung menjadi lebih efektif.

\section{METODE PENELITIAN}

\section{A. Rancangan Penelitian}

Penelitian eksperimental dengan jenis rancangan pre and post-test control group design. Penelitian ini bertujuan untuk membandingkan kombinasi PSWT dan LSSE dengan PSWT dan NM terhadap penurunan disabilitas punggung pada penderita HNP lumbosakral.

B. Tempat dan Waktu Penelitian

Penelitian berlangsung di Klinik Fisioterapi Denpasar dan Badung selama 4 bulan terhitung mulai awal bulan Februari 2018 sampai bulan Mei 2018. Intervensi terapi setiap sampel penelitian dilakukan sebanyak dua kali dalam seminggu selama empat minggu.

C. Populasi dan Sampel Penelitian

Populasi target merupakan seluruh pasien yang terindikasi menderita HNP lumbosakral di Denpasar dan Badung. Populasi terjangkau merupakan seluruh pasien yang terindikasi HNP lumbosakral dengan asesmen Fisioterapi ataupun rujukan dokter yang mengunjungi Klinik Fisioterapi di daerah Denpasar dan Badung dari bulan Februari 2018 - Mei 2018.

Berdasarkan perhitungan subjek, sampel berjumlah 11 orang pada masingmasing kelompok. Jumlah sampel ditambah $20 \%$ sehingga menjadi 14 orang.

D. Teknik Pengambilan Sampel

Pengambilan sampel/subjek penelitian secara simple random sampling. Peneliti melaksanakan randomisasi melalui teknik blocked randomization.

E. Prosedur Penelitian

1) Prosedur Pendahuluan :

a. Melakukan proses pengajuan ethical clearance ke bagian Litbang FK Unud/RSUP Sanglah.

b. Melakukan proses perijinan pada institusi tempat penelitian.

c. Penyebaran inform consent yang harus ditandatangani subjek penelitian.

d. Sebelum dan setelah intervensi, kedua kelompok penelitian dilakukan pengukuran disabilitas punggung bawah dengan kuesioner modified ODI. 
2) Prosedur Pelaksanaan Pengukuran Disabilitas Punggung

Pada saat pengukuran, responden diminta menunjukkan tingkat disabilitas punggung dengan mengisi kuesioner modified ODI setiap sebelum dan sesudah intervensi.

3) Prosedur Pelaksanaan Pengaplikasian PSWT

Adapun teknik pengaplikasian PSWT, sebagai berikut: Aplikasi PSWT diberikan dengan melakukan pengaturan timer dengan batas sampai 15 menit dengan arus pulsed dan intensitas yang diberikan mulai dari 48W. Aplikasi PSWT dihentikan sampai terjadi peningkatan suhu yang diinginkan pada jaringan.

4) Prosedur Pelaksanaan LSSE

LSSE terdiri atas: kontraksi isometric lumbar multifidus dan transversus abdominis, curl-up, pelvic bridge, side bridge, quadruped position with alternate arm/leg raises, dan prone plank. Setiap gerakan dilakukan dalam 10 set dengan 2 kali repetisi dengan frekuensi 2 kali dalam seminggu selama 4 minggu.

5) Prosedur Pelaksanaan NM

Penerapan mobilisasi saraf dengan memposisikan pasien dalam 2 posisi yaitu straight leg raising dan slump stretching. Intervensi dilakukan sebanyak 8x dengan teknik yang berbeda-beda. Pada intervensi $1 \& 2$, fokus intervensi ditujukan pada mechanical interface dengan melakukan opening technique dan kemudian closing technique. Pada intervensi 3 hingga 8, difokuskan pada struktur saraf dengan melakukan gerakan mobilisasi saraf dalam 4 tahapan yaitu position away \& move away, position toward \& move away, position away \& move toward, dan terakhir position toward \& move toward. Setiap gerakan ditahan selama 30 kali hitungan dan 5 kali repetisi, diawali dengan gerakan pasif oleh terapis dan diakhiri dengan gerakan aktif (self mobilization) oleh pasien.

\section{F. Analisis Data}

Analisis data sebagai berikut:
1. Statistik deskriptif menganalisa usia, tinggi badan, jenis kelamin, berat badan, penggunaan obat pereda nyeri.

2. Saphiro Wilk test digunakan untuk menguji normalitas data skor disabilitas punggung sebelum dan setelah intervensi pada masingmasing kelompok perlakuan.

3. Leven's Test digunakan untuk uji homogenitas data bertujuan untuk mengetahui variasi data skor disabilitas punggung.

4. Uji komparasi data skor disabilitas punggung sebelum dan setelah intervensi pada kelompok control dan perlakuan menggunakan uji komparasi non-parametrik yaitu Wilcoxon match test.

5. Uji komparasi non-parametrik yaitu Mann-Whitney U-test digunakan untuk membandingkan hasil skor disabilitas punggung setelah intervensi diantara kedua kelompok.

\section{HASIL PENELITIAN}

\section{Data Karakteristik Sampel}

Karakteristik sampel penelitian disajikan pada table 1.

Tabel 1 Distribusi Subjek Penelitian

Berdasarkan Usia, Jenis Kelamin, dan

Penggunaan Obat Pereda Nyeri

\begin{tabular}{cccc}
\hline & $\begin{array}{c}\text { Kelompok } \\
\text { Kontrol } \\
(\mathbf{n = 1 4 )}\end{array}$ & $\begin{array}{c}\text { Kelompok } \\
\text { Perlakuan } \\
(\mathbf{n = 1 4 )}\end{array}$ & $\begin{array}{c}\text { Nilai } \\
\mathbf{p}\end{array}$ \\
\hline $\begin{array}{c}\boldsymbol{f}(\boldsymbol{\%}) \\
\text { Karakteristik }\end{array}$ & & \\
\hline $\begin{array}{c}\text { Jenis } \\
\text { Kelamin (\%) }\end{array}$ & & & \\
Laki-laki & $9(64,29)$ & $10(71,43)$ & 0,691 \\
Perempuan & $5(35,71)$ & $4(28,57)$ & \\
Usia (tahun) & & & \\
Mean \pm SD & $46,86 \pm 3,55$ & $44,50 \pm 3,30$ & 0,080 \\
$\begin{array}{c}\text { Penggunaan } \\
\text { Obat Pereda } \\
\text { Nyeri (\%) } \\
\text { Ya }\end{array}$ & $3(21,43)$ & $4(28,57)$ & 0,668 \\
Tidak & $11(78,57)$ & $10(71,43)$ & \\
\hline & & &
\end{tabular}


Tabel 1 diatas menunjukkan karakteristik sampel berdasarkan jenis kelamin dengan total 28 orang.

Untuk melihat apakah terdapat perbedaan yang bermakna pada karakteristik usia atara kelompok kontrol dengan kelompok perlakuan digunakan uji independent sample t-test. Hasil uji didapatkan nilai $\mathrm{p}=0,080$ ( $p>0,05)$ yang berarti bahwa tidak terdapat perbedaan yang signifikan pada karakteristik usia antara kedua kelompok.

Hasil uji mann whitney u-test didapatkan nilai $\mathrm{p}=0,668 \quad(\mathrm{p}>0,05)$ berarti tidak ada perbedaan yang bermakna pada karakteristik penggunaan obat pereda nyeri antara kelompok kontrol dan kelompok perlakuan.

\section{Uji Normalitas dan Homogenitas}

Tabel 2 menyajikan uji normalitas dan uji homogenitas data sebelum dan setelah intervensi.

Tabel 2 Hasil Uji Normalitas dan Homogenitas Skor Modified ODI Sebelum dan Setelah Intervensi

\begin{tabular}{ccccc}
\hline $\begin{array}{c}\text { Klp } \\
\text { Data }\end{array}$ & \multicolumn{2}{c}{ Uji Normalitas } & \multicolumn{2}{c}{ Uji Homogenitas } \\
& $\begin{array}{c}\text { Klp } \\
\text { kontrol } \\
\text { (nilai p) }\end{array}$ & $\begin{array}{c}\text { Klp } \\
\text { perlaku } \\
\text { an } \\
\text { (nilai p) }\end{array}$ & $\begin{array}{c}\text { Klp } \\
\text { kontrol } \\
\text { (nilai p) }\end{array}$ & $\begin{array}{c}\text { Klp } \\
\text { perlaku } \\
\text { an } \\
\text { (nilai p) }\end{array}$ \\
\hline $\begin{array}{c}\text { Skor - } \\
\text { pre- } \\
\text { test }\end{array}$ & 0,517 & 0,020 & & \\
MODI & & & & \\
Skor & & & 0,521 & 0,287 \\
post- & 0,001 & 0,013 & & \\
test & & & & \\
MODI & & & & \\
\hline a: Shapiro Wilk test & & & \\
b: Levene's test & & & \\
\hline
\end{tabular}

Tabel 2 menunjukkan bahwa data skor disabilitas punggung sebelum dan setelah intervensi pada kelompok kontrol dan kelompok perlakuan tidak berdistribusi normal.

Uji homogenitas didapatkan nilai $\mathrm{p}=0,521$ atau $\mathrm{p}>0,05$ untuk skor modified ODI sebelum intervensi. Data skor modified ODI sesudah intervensi didapatkan nilai $\mathrm{p}=0,287$ atau $p>0,05$ yang menunjukkan bahwa data modified ODI sebelum dan setelah intervensi homogen.

Berdasarkan hasil uji normalitas, maka uji yang digunakan untuk pengujian hipotesis adalah uji statistik non-parametrik.

\section{Uji Beda Rerata Penurunan Nilai Modified Oswestry Disability Index Sebelum dan Sesudah Intervensi pada Kelompok Kontrol dan Perlakuan}

Tabel 3 merupakan hasil analisa skor modified ODI dengan Wilcoxon sign rank test.

Tabel 3. Hasil Analisis Skor Modified ODI dengan Wilcoxon Sign Rank Test

\begin{tabular}{|c|c|c|c|}
\hline \multirow{2}{*}{$\begin{array}{l}\text { Kelompo } \\
\text { k Data }\end{array}$} & $\begin{array}{c}\text { Sebelum } \\
\text { Intervensi }\end{array}$ & $\begin{array}{c}\text { Setelah } \\
\text { Intervensi }\end{array}$ & \multirow{2}{*}{$\begin{array}{c}\text { nilai } \\
\mathbf{p}\end{array}$} \\
\hline & $\begin{array}{c}\text { Median } \pm \text { IQ } \\
\text { R }\end{array}$ & $\begin{array}{c}\text { Median } \pm \text { IQ } \\
\text { R }\end{array}$ & \\
\hline Klp & $3150+300$ & & 0,00 \\
\hline Kontrol & $31,50 \pm 3,00$ & $15,00 \pm 3,00$ & 1 \\
\hline Klp & $3200+300$ & & 0,00 \\
\hline Perlakuan & & $14,00 \pm 2,25$ & 1 \\
\hline
\end{tabular}

Berdasarkan Tabel 3 didapatkan hasil penurunan nilai modified ODI yang dianalisis dengan Wilcoxon sign rank test sebelum dan sesudah intervensi pada kelompok kontrol dengan nilai $\mathrm{p}=0,001$ yang berarti bahwa terdapat perbedaan yang bermakna pada penurunan nilai modified ODI sebelum dan sesudah kombinasi PSWT dan LSSE. Di kelompok kontrol sebelum intervensi separuh sampel memiliki skor disabilitas punggung lebih besar dan lebih kecil dari 31,50. Data setelah intervensi menunjukkan bahwa separuh sampel pada kelompok kontrol memiliki skor disabilitas punggung lebih besar dan lebih kecil dari 15,00.

Pada data penelitian terdapat perbedaan pada Quartile 3 yaitu pada data pre-test dari 33,00 menjadi 17,00 pada post test. Hal ini menunjukkan bahwa terdapat penurunan batas atas nilai disabilitas punggung. Pada nilai interquartile range antara pre-test dan post-test tidak terdapat perubahan. Maka disimpulkan bahwa rentang nilai disabilitas punggung pada kelompok kontrol tetap. 
Dari segi kategori penurunan disabilitas, terdapat penurunan rerata kategori pada kelompok kontrol. Pada saat pre-test, sampel penelitian pada kelompok kontrol masuk ke dalam kategori cripple disability dengan rerata persentase disabilitas punggung sebesar $63,58 \%$, sedangkan setelah post-test, sampel penelitian pada kelompok kontrol masuk ke dalam kategori moderate disability dengan rerata persentase disabilitas punggung sebesar $32,72 \%$.

Pengujian hipotesis sebelum dan sesudah intervensi pada kelompok perlakuan dengan Wilcoxon sign rank test didapatkan nilai $\mathrm{p}=0,001$ yang menunjukkan bahwa ada perbedaan yang bermakna pada penurunan nilai modified ODI sebelum dan setelah kombinasi intervensi PSWT dan NM. Pada kelompok perlakuan sebelum intervensi separuh sampel memiliki skor disabilitas punggung lebih besar dan lebih kecil dari 32,00. Data setelah intervensi menunjukkan bahwa separuh sampel pada kelompok perlakuan memiliki skor disabilitas punggung lebih besar dan lebih kecil dari 14,00.

Pada data penelitian terdapat perbedaan pada Quartile 3 yaitu pada data pre-test dari 33,00 menjadi 15,25 pada post test. Hal ini menunjukkan bahwa terdapat penurunan batas atas nilai disabilitas punggung. Pada nilai interquartile range antara pre-test dan post-test terdapat perubahan berupa penurunan nilai interquartile range. Maka disimpulkan rentang nilai disabilitas punggung pada kelompok perlakuan menjadi semakin dekat.

Dari segi kategori penurunan disabilitas, terdapat penurunan rerata kategori pada kelompok perlakuan. Pada saat pre-test, sampel penelitian pada kelompok perlakuan masuk ke dalam kategori cripple disability dengan rerata persentase disabilitas punggung sebesar $64,28 \%$, sedangkan setelah post-test, sampel penelitian pada kelompok perlakuan masuk ke dalam kategori moderate disability dengan rerata persentase disabilitas punggung sebesar $29,00 \%$.
4. Uji Beda Post-Test Penurunan Nilai Modified Oswestry Disability Index Sebelum dan Setelah Intervensi

antara Kelompok Kontrol dan

\section{Perlakuan}

Perbandingan penurunan nilai posttest modified ODI antara sebelum dan sesudah intervensi pada kedua kelompok yang diberikan intervensi PSWT dan LSSE pada kelompok kontrol dan intervensi PSWT dan NM pada kelompok perlakuan diuji dengan Mann-Whitney U-test. Hasil uji tertera pada Tabel 4 berikut.

Tabel 4 Hasil Uji Mann-Whitney U-Test

\begin{tabular}{cccc}
\hline & $\begin{array}{c}\text { Kelompok } \\
\text { Data }\end{array}$ & Median \pm IQR & $\begin{array}{c}\text { nilai } \\
\text { p }\end{array}$ \\
\hline $\begin{array}{c}\text { Pre- } \\
\text { Test }\end{array}$ & $\begin{array}{c}\text { Kelompok } \\
\text { Kontrol }\end{array}$ & $31,50 \pm 3,00$ & \\
& $\begin{array}{c}\text { Kelompok } \\
\text { Perlakuan }\end{array}$ & $32,00 \pm 3,00$ & 0,944 \\
\hline Post - & $\begin{array}{c}\text { Kelompok } \\
\text { Kest }\end{array}$ & $15,00 \pm 3,00$ & \\
& Kontrol & & 0,044 \\
& Kelompok & $14,00 \pm 2,25$ & \\
\hline
\end{tabular}

Tabel 4 memperlihatkan hasil perhitungan beda rerata penurunan nilai modified ODI yang diperoleh yaitu nilai $\mathrm{p}=0,044$ atau $\mathrm{p}<0,05$ pada post-test antara kedua kelompok intervensi. Hal ini berarti ada perbedaan yang bermakna di antara kedua pelatihan.

Persentase relatif penurunan selisih skor modified ODI pada kelompok perlakuan lebih besar daripada kelompok kontrol. Persentase relatif pada kelompok kontrol sebesar $48,54 \%$, sedangkan persentase relatif pada kelompok perlakuan sebesar $54,88 \%$. Dengan demikian, dapat dikatakan bahwa intervensi kelompok perlakuan menghasilkan penurunan nilai modified ODI lebih besar daripada intervensi kelompok kontrol.

\section{PEMBAHASAN}

\section{Efektivitas Kombinasi Pulsed \\ Shortwave Therapy dan Lumbar Spine \\ Stabilization Exercise dalam \\ Menurunkan Disabilitas Punggung pada Pasien Hernia Nukleus Pulposus Lumbosakral di Klinik Fisioterapi Badung dan Denpasar}

Penurunan nilai disabilitas punggung telah diuji secara statistik dengan uji wilcoxon test menunjukkan bahwa data memiliki nilai 
yang signifikan bahwa penurunan nilai disabilitas punggung pada kelompok perlakuan PSWT dan LSSE secara statistik menunjukkan perbedaan yang bermakna.

Pada pasien HNP lumbosakral terjadi suatu kondisi yang disebut sebagai fear avoidance belief yaitu ketakutan untuk bergerak atau merasakan nyeri sebagai akibat dari melakukan suatu aktivitas. Ketakutan dalam bergerak ini menyebabkan seseorang membatasi pergerakannya, sehingga otot yang seharusnya menstabilisasi kolumna vertebra tidak aktif dan otot global menjadi hiperaktif dan memicu terjadinya spasme otot. ${ }^{2}$

Diathermy merupakan aplikasi dari penggunaan gelombang elektromagnetik berfrekuensi tinggi yang bertujuan untuk menghasilkan panas bagi jaringan tubuh. Penelitian terdahulu membuktikan bahwa PSWT dengan average power $48 \mathrm{~W}$ dapat meningkatkan suhu jaringan sampai kedalaman $3 \mathrm{~cm}$ dengan peningkatan mencapai $4,6^{\circ} \mathrm{C} .^{5}$ Hal ini dikarenakan mekanisme kerja PSWT yang mempengaruhi (1) reaksi metabolik, (2) efek vaskular, (3) efek neuromuskular, dan (4) efek pada connective tissue.

Pada penderita HNP lumbosakral terjadi disfungsi pada subsistem pasif, aktif, dan neural. Disfungsi pada subsistem pasif dapat disebabkan oleh cedera mekanik seperti overstretch pada ligamen, adanya kerobekan pada annulus, microfractures pada endplate, serta ekstrusi material diskus ke badan vertebra. Struktur ini dapat dilemahkan melalui proses degenerasi atau adanya penyakit tertentu. Disfungsi pada subsitem aktif dapat diperburuk oleh karena ketidakmampuan dalam menerima dan menghantarkan respon neural, memberikan umpan balik yang akurat terkait informasi ketegangan otot unit kontrol neural. Oleh karena itu, kapasitas stabilisasi dari kolumna spinalis menjadi berkurang. Keadaan ini akan menyebabkan mekanisme kompensasi dari subsistem pasif untuk menahan pergerakan dinamis yang tidak terduga. Disfungsi subsistem neural berkaitan dengan penerimaan stimulus mekanoreseptor sampai kepada unit pengolahnya. Apabila sinyal yang ditransmisikan tidak sesuai atau terdapat permasalahan pada unit pengolah tentu hasil olahan berupa gerakan dapat ditransmisikan lebih cepat ataupun lebih lambat sehingga menyebabkan stabililitas pada kolumna verterba menjadi kurang tepat. Hal seperti ini akan memunculkan permasalahan terkait area kolumna spinalis seperti nyeri punggung bawah. ${ }^{6,7}$

Penelitian lainnya menyimpulkan bahwa penurunan skor disabilitas punggung bermakna pada penderita HNP setelah diberikan lumbar spine stabilization exercise. ${ }^{8,3}$ Hal ini sesuai dengan hasil penelitian dimana ditemukan nilai $(\mathrm{p}<0,05)$ dimana aktivitas yang efektif dari otot-otot yang melekat di sekitar vertebra akan membantu meningkatkan stabilitas kolumna vertebra. Penelitian dari (Bakhtiari, et.al., 2005) membuktikan bahwa LSSE pada pasien HNP lumbal meningkatkan stabilitas pada segmen lumbar yang mengalami cedera sehingga meningkatkan kemampuan fungsional pasien dalam melaksanakan tugas (mengurangi waktu dalam menyelesaikan tugas) dan dapat melakukan tugas dengan lebih mudah serta nyaman. Hide membuktikan bahwa LSSE dapat meningkatkan ukuran dari otot multifidi. Rissanen juga menemukan bahwa LSSE dapat meningkatkan kekuatan ekstensor lumbar dikarenakan LSSE dapat mencegah atrofi pada serabut otot tipe II otot multifidi, meningkatkan ukuran serabut otot sebesar $11 \%$, serta meningkatkan daya ledak pada otot sebesar $19-22 \% .^{9}$

\section{Efektivitas Kombinasi Pulsed Shortwave Therapy dan Neurodynamic Mobilization dalam Menurunkan Disabilitas Punggung pada Pasien Hernia Nukleus Pulposus Lumbosakral di Klinik Fisioterapi Badung dan Denpasar}

Penurunan nilai disabilitas punggung didapatkan nilai $\mathrm{p}<0,05$. Penurunan nilai disabilitas punggung pada kelompok intervensi PSWT dan NM secara statistik menunjukkan perbedaan yang bermakna.

Lehmann dalam (Prentice et.al., 2002) menyebutkan bahwa peningkatan suhu pada jaringan sebesar $1^{\circ} \mathrm{C}$ dapat mengurangi 
inflamasi dan meningkatkan metabolism, peningkatan suhu $2-3^{\circ} \mathrm{C}$ akan mengurangi nyeri dan spasme otot, sedangkan peningkatan suhu lebih dari $3-4^{\circ} \mathrm{C}$ akan meningkatkan ekstensibilitas jaringan sehingga memungkinkan praktisi untuk mengobati permasalahan kronis pada jaringan. ${ }^{10}$ Peneliti lainnya meyakini bahwa pemanasan optimal pada suhu jaringan sebaiknya dicapai pada suhu di atas $38-40^{\circ} \mathrm{C}$ atau peningkatan $3-4^{\circ} \mathrm{C}$ di atas baseline. Penelitian lainnya menyimpulkan bahwa terdapat perbaikan yang signifikan pada pasien chronic low back pain setelah pemberian PSWT dengan intensitas $50 \mathrm{~W}$ yang dikombinasikan dengan pemberian NM. ${ }^{11}$

NM termasuk satu teknik manual terapi untuk meningkatkan mobilitas dari pada sistem saraf terhadap mechanical interfacenya. ${ }^{4}$ NM memiliki peran penting dalam manajemen nyeri dan meningkatkan mobilitas pada akar saraf. Ketika akar saraf mengalami tekanan dan mikro sirkulasi mengalami gangguan, tekanan yang diterima oleh akar saraf dapat menyebabkan edema dan dimielinisasi.

Teknik NM meliputi gerakan osilasi pendek terbukti dapat mengurangi edema sehingga kemudian mengurangi hipoksia dan gejala yang ditimbulkan. Teknik NM dapat membantu mengurangi kompresi saraf, gaya friksi dan gaya tension sehingga mengurangi sensitivitas mekanis pada sistem saraf. Teknik NM dapat meningkatkan fungsi mekanis pada struktur saraf seperti fungsi tension dan fungsi sliding. Ketika struktur saraf mengalami penjepitan dan mengalami gangguan dalam hal mobilitas, maka nyeri akan timbul sepanjang saraf tersebut. Teknik neurodynamic sliding berperan besar dalam meningkatkan sirkulasi darah dan transport aksonal serta meningkatkan integritas saraf dan mampu mengurangi tekanan yang disebabkan oleh fibrosis intraneural dan eksstraneural. Selama pergerakan normal, aliran darah saraf selalu mengalir seiring dengan distorsi yang terjadi pada pembuluh darah dan saraf. Ketika struktur saraf mengalami iritasi, maka akan terjadi peningkatan ketegangan (neural tension) oleh karena fibrosis jaringan. Diketahui bahwa beberapa efek dari ketegangan saraf meliputi berkurangnya aliran darah intraneural (8\%$15 \%$ ), iskemia jaringan saraf serta menurunnya konduktivitas saraf tersebut. ${ }^{4}$

\section{Kombinasi Pulsed Shortwave Therapy} dan Neurodynamic Mobilization lebih Efektif Menurunkan Disabilitas Punggung dibandingkan Kombinasi Pulsed Shortwave Therapy dan Lumbar Spine Stabilization Exercise pada Pasien Hernia Nukleus Pulposus Lumbosakral di Klinik Fisioterapi Denpasar dan Badung

Penurunan nilai disabilitas punggung pada penelitian ini dengan nilai $\mathrm{p}<0,05$. Hal ini menunjukkan bahwa terdapat perbedaan nilai rerata post-test skor disabilitas punggung yang bermakna secara statistik. Persentase relatif penurunan skor disabilitas punggung yang lebih besar ditunjukkan oleh intervensi kombinasi pulsed shortwave therapy dan neurodynamic mobilization yaitu sebesar $54,88 \%$.

Waktu intervensi selama 4 minggu. Dalam rentang waktu 4 minggu tersebut, intervensi kombinasi PSWT dan LSSE menjadi kurang signifikan diakibatkan efek yang diharapkan muncul pada pasien HNP grade 1 dan 2 baru bisa dirasakan setelah aplikasi lebih dari 6 minggu, sehingga menjadikan kombinasi PSWT dan NM menjadi lebih unggul. ${ }^{3,12}$

Penelitian dari Draper, et.al. (2013) membuktikan bahwa PSWT dengan average power $48 \mathrm{~W}$ dapat meningkatkan suhu jaringan sampai kedalaman $3 \mathrm{~cm}$ dengan peningkatan mencapai $4,6^{\circ} \mathrm{C}$. Dengan peningkatan suhu yang optimal, maka oksigen akan lebih banyak tersedia di jaringan. Dengan demikian, akan banyak nutrisi yang tersedia sebagai bahan dalam reparasi jaringan. ${ }^{5,11}$

NM merupakan suatu teknik manual terapi yang ditujukan untuk meningkatkan mobilitas sistem saraf terhadap jaringan di sekitarnya melalui pergerakan trunk, ekstremitas atas dan bawah yang sistematis. Teknik ini bertujuan untuk meningkatkan mikrosirkulasi intraneural dan meningkatkan 
fungsi mekanis struktur saraf dalam hal tension, sliding, dan compression.

Penjelasan yang tepat terhadap perbaikan tingkat nyeri dan disabilitas fungsional yang dialami oleh pasien dengan teknik intervensi mobilisasi saraf adalah bahwa teknik neurodynamic yang dapat mempengaruhi fungsi mekanik pada saraf perifer, dan perubahan fungsi mekanis saraf ini berdampak langsung pada perubahan fisiologis struktur saraf. ${ }^{13,14}$ Penelitian berhasil menunjukkan bahwa mobilisasi saraf menghasilkan pemanjangan longitudinal dan regangan dalam jumlah tinggi. Teknik mobilisasi saraf membantu memulihkan pergerakan antara saraf dan struktur sekitarnya melalui gerakan sliding.

Oleh karena itu, tekanan intrinsik pada jaringan saraf menurun yang kemudian meningkatkan fungsi saraf. Kompresi akar saraf karena herniasi disk menghambat aliran darah di dalam akar saraf, perubahan mikrosirkulasi saraf ini menyebabkan rasa nyeri dan pelepasan mediator inflamasi. Selebihnya, terjadi blok pada sistem konduksi saraf, edema, dan sensitisasi mekanik juga dihasilkan dari kompresi akar saraf. Teknik mobilisasi saraf membantu meningkatkan aliran darah intraneural, aliran axoplasmic, aktivasi simpatis yang selanjutnya, membantu dalam penyerapan cairan pada jaringan dan mengurangi edema intraneural. ${ }^{4,13,14,15}$

\section{SIMPULAN}

Simpulan pada penelitian ini, yaitu:

1. Kombinasi pulsed shortwave therapy dengan lumbar spine stabilization exercise efektif dalam menurunkan disabilitas punggung pada pasien hernia nukleus pulposus lumbosakral di klinik Fisioterapi Badung dan Denpasar sebesar $48,54 \%$.

2. Kombinasi pulsed shortwave therapy dengan neurodynamic mobilization efektif dalam menurunkan disabilitas punggung pada pasien hernia nukleus pulposus lumbosakral di klinik Fisioterapi Badung dan Denpasar sebesar $54,88 \%$.

3. Kombinasi pulsed shortwave therapy dan neurodynamic mobilization lebih efektif daripada kombinasi pulsed shortwave therapy dan lumbar spine stabilization exercise dalam menurunkan disabilitas punggung pada pasien hernia nukleus pulposus lumbosakral di klinik Fisioterapi Badung dan Denpasar.

\section{DAFTAR PUSTAKA}

1. Maliawan, S. \& Mahadewa, T. 2009. Diagnosa dan Tatalaksana Kegawat Daruratan Tulang Belakang. Jakarta. FK UI

2. Nasikhatussoraya, N. 2016. Hubungan Intensitas Nyeri dan Disabilitas Aktivitas Sehari-hari dengan Kualitas Hidup. Semarang: Fakultas Kedokteran Universitas Diponegoro

3. Ye, C., Ren, J., Zhang, J., Wang, C., Liu, Z., Li, F., Sun, T. 2015. Comparison of Lumbar Spine Stabilization Exercise Versus General Exercise in Young Male Patients with Lumbar Disc Herniation after 1 Year of Follow Up. Int J Clin Exp Med. 8(6): 9869 - 9875

4. Shacklock MO. 2005. Clinical Neurodynamics: a New System of Musculoskeletal Treatment. Edinburg, UK. Elsevier Health Sciences

5. Draper, DO., Hawkes, AR., Johnson, AW., Diede, MT., dan Rigby, JH. 2013. Muscle Heating with Megapulse II Shortwave Diathermy and Rebound Diathermy. J Ath Train 48: 477 - 482

6. McGill, SM., Grenier, S., Kavcic, N., dan Cholewicki, J. 2003. Coordination of Muscle Activity to Assure Stability of the Lumbar Spine. Journal of Electromyography and Kinesiology. $13 \mathrm{p}$ $353-359$

7. Panjabi, MM. 1992. The Stabilization of The Spine. Part 1. Function, Dysfunction, Adaptation, and Enhacement. Journal of Spinal Disorders 5. 383 - 389

8. Barr, KP., Griggs, M., Cadby, T., 2007. Lumbar Stabilization: A Review of Core Concepts and Current Literature, Part 2. American Journal of Physical Medicine \& Rehabilitation 86: $72-80$

9. Bakhtiari, AB., Farokhi, ZS., dan Rezasoltani,A., 2005. Lumbar Stabilizing Exercises Improve Activities of Daily 
Living in Patients with Lumbar Disc

Herniation. Journal of Back and Musculoskeletal Rehabilitation 18:55 60

10. Prentice W, Quillen WS, Underwood F. 2002. Therapeutic Modalities for Physical Therapy Second Edition. United States of America. The McGraw-Hill Company : 272-303

11. Michlovits, SL., Bellew, JW., dan Nolan, TP. 2012. Modalities for Therapeutic Intervention: Fifth Edition. Philadelphia: FA Davis Company

12. Ahmed, S., Hassan, T., Hanif, A. 2012. Effects of Lumbar Stabilization Exercise in Management of Pain and Restoration of Function in Patients with Postero Lateral Disc Herniation. Annals. 18 (2): $152-157$

13. Ellis RF, Hing WA. 2008. Neural mobilization: a systematic review of randomized controlled trials with an analysis of therapeutic efficacy.J Man ManipTher. 16(1):8-22

14. Kumar V , GoyalM, RajendranN, Narkeesh D. 2013. Effect of neural mobilization on monosynaptic reflex $-a$ pretest posttest experimental design. International Journal of Physiotherapy and Research. 3:58- 62

15. Butler DS. The Sensitive Nervous System. Noigroup Publications, Adelaide Australia. 2000 